\title{
The effect of preoperative respiratory physiotherapy and motor exercise in patients undergoing elective cardiac surgery: short-term results
}

\author{
Paolo Nardi ${ }^{1}$, Antonio Pellegrino ${ }^{1}$, Calogera Pisano ${ }^{1}$, Sara Rita Vacirca ${ }^{1}$, Deborah Anselmi ${ }^{2}$, Silvia Saulle ${ }^{3}$, \\ Romana Dandi ${ }^{3}$, Alessia Romano ${ }^{3}$, Annamaria Servadio ${ }^{4}$, Alessandra Gianlorenzi ${ }^{5}$, Giovanni Ruvolo ${ }^{1}$ \\ ${ }^{1}$ Cardiac Surgery Division, Tor Vergata University Hospital, Rome, Italy \\ ${ }^{2}$ Degree of Physiotherapy, Tor Vergata University Hospital, Rome, Italy \\ ${ }^{3}$ Physiotherapy Service, Tor Vergata University Hospital, Rome, Italy \\ ${ }^{4}$ Management Coordinator Rehabilitation Area, Tor Vergata University Hospital, Rome, Italy \\ ${ }^{5}$ Management Coordinator Cardiac Surgery Unit, Tor Vergata University Hospital, Rome, Italy
}

Kardiochirurgia i Torakochirurgia Polska 2019; 16 (2): 81-87

\begin{abstract}
Introduction: Loss of physical activity and pulmonary dysfunction with its associated complications represent two of the most important causes of morbidity and mortality following cardiac surgery. Few studies have investigated the effects of preoperative interventions targeted at improving cardiorespiratory and musculoskeletal function in the postoperative period.

Aim: To evaluate whether a physiotherapy program based on respiratory training with or without musculoskeletal mobilization, started preoperatively, may provide a significant improvement in pulmonary and musculoskeletal recovery postoperatively in patients undergoing elective cardiac surgery.

Material and methods: Patients with similar baseline and preoperative characteristics were randomly assigned to a preoperative respiratory physiotherapy protocol (group A), a preoperative respiratory and motor physiotherapy protocol (group B), or no preoperative specific physiotherapy protocol but only a simplified perioperative standard physiotherapy protocol (control group or group C). Group A consisted of 19 patients, group B of 20, group C of 20. Data on 6-minute walking test, peak expiratory flow, and from blood gas analysis were retrospectively analyzed.

Results: As compared with group C, a statistically significant improvement was observed in the two preoperatively treated groups $A$ and $B$ in terms of longer pre- and postoperative distance traveled at the 6-minute walking test, better pre- and postoperative peak expiratory flow value, and better $\mathrm{PaO}_{2}$ and $\mathrm{SaO}_{2}$ values in postoperative blood gas measurements ( $p<0.05$, for all comparisons). A statistically significant reduction of the postoperative length of in-hospital stay was also observed in group B.
\end{abstract}

Conclusions: As compared with the control group, substantially better clinical results for respiratory and musculoskeletal function were found in the groups preoperatively treated with

\section{Streszczenie}

Wprowadzenie: Utrata aktywności fizycznej i dysfunkcja płuc oraz towarzyszące im powikłania stanowią dwie najważniejsze przyczyny zachorowalności i śmiertelności po operacjach kardiochirurgicznych. W niewielu badaniach zajmowano się określeniem wpływu interwencji przedoperacyjnych mających na celu poprawę czynności układu krążenia i układu mięśniowo-szkieletowego na okres pooperacyjny.

Cel: Ocena, czy program fizjoterapii oparty na treningu oddechowym z mobilizacją lub bez mobilizacji układu mięśniowo-szkieletowego rozpoczęty przed operacją przynosi znaczącą poprawę funkcji płuc i układu mięśniowo-szkieletowego po planowej operacji kardiochirurgicznej.

Materiat i metody: Pacjentów z podobnymi parametrami wyjściowymi i przedoperacyjnymi losowo przydzielono do przedoperacyjnego protokołu fizjoterapii oddechowej (grupa A), przedoperacyjnego protokołu fizjoterapii oddechowej i ruchowej (grupa B) lub nie przydzielono ich do żadnego konkretnego protokołu fizjoterapii przedoperacyjnej, a jedynie do protokołu uproszczonej standardowej fizjoterapii okołooperacyjnej (grupa C). Grupa A obejmowała 19 pacjentów, a grupy B i C po 20 pacjentów. Dane dotyczące testu marszowego (6MWD), szczytowego przepływu wydechowego i analizy gazometrii zostały poddane analizie retrospektywnej.

Wyniki: W porównaniu z grupą C w grupach A i B zaobserwowano statystycznie istotnie lepsze wyniki pod względem odległości pokonanej w teście marszowym przed i po operacji, szczytowej wartości przepływu wydechowego przed i po operacji oraz wartości $\mathrm{PaO}_{2}$ i $\mathrm{SaO}_{2}$ w pooperacyjnych pomiarach gazometrii ( $p<0,05$, dla wszystkich porównań). W grupie $B$ stwierdzono również statystycznie istotnie krótszy czas pobytu w szpitalu po operacji.

Wnioski: W porównaniu z grupą kontrolną w grupach, w których przed operacją zastosowano protokoły fizjoterapeutyczne, stwierdzono znacznie lepsze wyniki kliniczne dotyczące

Address for correspondence: Paolo Nardi MD, PhD, Tor Vergata University Hospital, Viale Oxford 81, 00133 Rome, Italy, phone: +39 (06) 20903584, fax: +39 (06) 20903538, e-mail: pa.nardi4@libero.it

Received: 2.02.2019, accepted: 11.05.2019. 
physiotherapeutic protocols immediately before as well as after cardiac surgery.

Key words: physiotherapy, motor exercise, cardiac surgery.

\section{Introduction}

Loss of physical activity and pulmonary dysfunction, with its associated complications such as secretion retention, atelectasis and pneumonia, represent one of the most important causes of morbidity and mortality in the period following cardiac surgery.

The impairment of pulmonary function has several causes, including sternotomy for the surgical treatment of cardiac diseases, pleurotomy for the harvesting of the internal mammary artery as a graft for coronary artery bypass surgery, pleural drain insertion, and dysfunction of the phrenic nerve due to the use of cold cardioplegic solutions [1-5]. Moreover, older and increasingly frail patients are now referred for cardiac surgery, representing a specific subgroup at higher risk of pulmonary complications [6-9].

Since the phenotype of a frail patient is characterized by reduction in muscle mass, strength, endurance and activity level, perioperative rehabilitation protocols, aimed at maintaining adequate lung function and allowing faster mobilization, can be very important to reduce postoperative complications related to immobilization and therefore lead to a more rapid recovery after cardiac surgery [10-13].

While postoperative rehabilitation programs following cardiac surgery have been shown to improve short-term outcomes, few studies have investigated the effects of preoperative interventions targeted at improving cardiorespiratory and musculoskeletal function in the postoperative period $[1,14,15]$.

\begin{abstract}
Aim
The purpose of this study was to evaluate whether a physiotherapy treatment started in the preoperative phase and based on respiratory training with or without musculoskeletal mobilization may provide a significant improvement of postoperative pulmonary and musculoskeletal recovery in patients undergoing electively cardiac surgery, in comparison to the use of a simplified perioperative standard physiotherapy protocol.
\end{abstract}

\section{Material and methods}

The experimental investigation was carried out at the Cardiac Surgery Unit of the Tor Vergata University Hospital of Rome. The study took place during a period of 6 months, May-November 2017. A total of 65 patients (mean age: 63.6 \pm 10.7 years) were screened for the study. The study was approved by the Institutional Review Board of the Tor Vergata University Hospital, which waived the need for patient consent. The study was designed as a retrospective one. funkcji układu oddechowego i mięśniowo-szkieletowego zarówno bezpośrednio przed operacją kardiochirurgiczną, jak i po niej.

Słowa kluczowe: fizjoterapia, ćwiczenia ruchowe, operacja kardiochirurgiczna.

\section{Groups of patients}

The study considered two groups of patients (group A and group B) treated preoperatively and postoperatively, and a control group of patients (group C) treated with a simplified physiotherapy standard respiratory and walking protocol, in order to avoid complications related to the absence of movement.

\section{Enrollment criteria}

Inclusion criteria adopted to enroll the patients in the study were chronic obstructive pulmonary disease with a NYHA class I, II, III, good exercise tolerance at the time of in-hospital admission, and chance to take benefit from respiratory and motor treatment. In particular, even patients with NYHA class III reported in their history, but deemed able to perform the exercise protocols, carried out the study protocol, obviously always under the control of the doctor during the exercises, especially of the 6-minute walking test (6MWT).

Exclusion criteria were the presence of NYHA class IV, patients on dialysis treatment or affected by neurological dysfunction and unable to understand the physiotherapist's indications, patients affected by disabling osteo-articular diseases, acute coronary syndrome, or the need for emergency surgical interventions.

The physiotherapy treatment consisted of three phases: preoperative treatment in the cardiac surgery department, postoperative treatment in the intensive care unit, and postoperative treatment in the cardiac surgery department. Patients were instructed on exercises to be done by the physiotherapist. All breathing and muscle exercises were performed by each patient individually in the presence of the physiotherapist, under the supervision of the physician.

\section{Measurements}

The 6-minute walking test was performed in all three groups of patients (recruited in the study) the day before cardiac surgery and the last day before discharge from the hospital. The 6MWT allowed us to evaluate the ability to perform normal daily activities or, conversely, the degree of functional limitation. The test was conducted according to standard protocols, using a corridor with a length of $25 \mathrm{~m}$ bounded by a colored ribbon on the floor. Every minute the patients were encouraged with standard phrases (i.e. "it's going well", "keep going well"). The patients had the opportunity to stop or take breaks during the test, but at the same time they were asked to start walking again as 
soon as possible. A stopwatch was used to keep the time of 6 minutes and an external operator counted the number of laps performed. Before the beginning of the walk and at the end of the $6 \mathrm{~min}$, a Borg scale value was assigned to indicate the degree of breathlessness, in terms of dyspnea, chest pain, confusion, or leg pain on a scale of 0 (nothing) to 10 (severe) $[16,17]$.

At the time of initial admission and on the last day of postoperative treatment, an arterial blood sample (blood gas analysis) was taken, through which the changes and the differences in cardiorespiratory function were observed following surgery and physiotherapy treatment. The parameters taken into consideration were $\mathrm{pH}$, partial arterial pressure of carbon dioxide $\left(\mathrm{PaCO}_{2}\right)$, partial arterial pressure of oxygen $\left(\mathrm{PaO}_{2}\right)$, arterial oxygen saturation $\left(\mathrm{SaO}_{2}\right)$, total concentration of hemoglobin ( $\mathrm{THb}$ ) and concentration of bicarbonate ion $\left(\mathrm{HCO}_{3}\right)$.

All the patients were evaluated by the peak expiratory flow (PEF) method, i.e. the highest expiratory flow obtained during a forced expiratory maneuver performed immediately after a maximal inhalation.

Through the PEF it was possible to evaluate the forced expiratory force the day before surgery, and at discharge twice a day (morning-afternoon), in order to monitor any changes or improvements of the elastic property of the lungs and of the force generated by the respiratory musculature, especially the abdominal muscles [18-20].

Physiotherapy protocols in the groups of patients $(A, B)$ subjected to treatment

In the preoperative phase, patients were informed about the importance of the early mobilization carried out in the following $24 \mathrm{~h}$, of keeping the seated position in the chair, followed by the standing station and walking, in order to favor the physiological re-expansion of the lungs. These protocols have been used in the subjects belonging to both groups A and B. In particular, patients of both groups learned deep breathing exercises through long and deep current volume breaths, to maintain a short apnea and to perform one or two coughing strokes followed by a slow and gentle exhalation with half-closed lips. Thoracic and abdominal breathing were taught to mobilize different lung areas in order to obtain better lung ventilation, and the use of volume and flow incentive was taught to promote deep inhalation training with an open glottis (aimed at lung parenchymal re-expansion). Finally, patients learned the positive exhalation pressure (PEP) technique using a PEP bottle to facilitate bronchial drainage and to prevent atelectasis $[18,21]$.

Group A and B patients underwent the same respiratory treatment, mainly with exercises based on respiratory muscle training: 1. Keeping their hands on their abdomen, a) inhaling from the nose using abdominal muscles, b) exhaling by blowing from the mouth. 2. Keeping their hands resting on the upper part of their thorax, a) inhaling from the nose using chest muscles, b) exhaling from the mouth. 3. Keeping their hands on their chest, a) inhaling keeping their arms outstretched, b) exhaling bringing their hands back to their chest. 4. Putting their hands on their chest, a) inhaling keeping their arms outstretched, b) exhaling bringing their hands back to their chest. 5. Keeping their hands on their chest, a) inhaling with their arms outstretched upwards, b) exhaling bringing their hands back to their chest. 6 . Keeping their arms along sides, a) inhaling bringing their arms forward and up, b) exhaling bringing their arms back out and down along sides. 7. Keeping their hands behind their nape with elbows forward, a) breathing expanding their elbows, b) exhaling closing their elbows. 8. Keeping their hands to their hips, a) inhaling, b) exhaling by rotating their trunk to the right, c) inhaling, d) exhaling by rotating their trunk to the left.

Group A and B patients were taught the self-drainage technique, i.e. using mainly the expiratory flow to mobilize bronchial secretions. The goal was to achieve the highest possible expiratory flow rate in the bronchi, without performing a forced expiration, but by regulating the force with which exhalation takes place. It is controlled breathing through three phases of exercise: detachment of the mucus from the periphery of the lung with low lung volume respiration, collection of medium-sized airway mucus through low and medium volume lung respirations, removal of mucus from large bronchi with respiration at medium and high pulmonary volume.

Group B patients performed active movements of their upper and lower limbs, with muscle stretching and relaxation. The exercises were performed in bed and in a standing position, including: 1. Passive and active assisted mobilization of their four limbs against variable resistance; the mobilization against resistance was performed at low load and assisted by the physiotherapist. 2. Flexion of their knees to the chest by accompanying flexion with their hands. 3. Bending their legs without raising their heels, and back. 4. Moving a limb backwards with an extended knee and bending the supporting leg. 5. Extension of the hip with an extended knee. 6. Lifting their heels from the ground. 7. Extension of their knee with the foot flexed dorsally, and back. 8. Raising one leg, bending the knee and crossing it on the other leg. 9. Abduction and adduction of their legs. 10. Flexion and extension of their limbs for 1 minute. 11. Go up and down small steps. 12. Extension of their arms up and back with hands on their shoulders. 13 Eight small rotations of the arms for two minutes forward and back. 14. Torsion of their trunk from one side to the other.

Group C patients in this phase performed a standard preoperative preparation, consisting of breathing exercises of the chest and abdomen with associated postural passages up to assisted walking.

In the postoperative intensive care unit, the aim of physiotherapy for all the three groups was early mobilization associated with stimulation of thoracic and abdominal breathing in order to accelerate the delicate phases of awakening and weaning from the mechanical ventilation. Treatment consisting in assisted active-passive mobilization, assisted cough, slight postural changes, breathing ex- 
ercises was performed daily for all the patients, generally for two days or longer $[19,20]$.

If the period of stay in intensive care was longer, the treatment plan was modified in accordance with gradual progression of the clinical status, i.e. acquisition of sitting position, standing position, passage from bed to chair.

Finally, in the ward, group A and B patients performed respiratory exercises with or without motor exercises as indicated during the period of education of the preoperative phase, progressively starting from the first to the sixth day up to the achievement of complete respiratory and motor autonomy.

Group C patients were only helped in postural passages and assisted walking, and their clinical conditions were assessed daily.

\section{Statistical analysis}

Statistical analysis was performed with the Stat View 4.5 program (SAS Institute Inc, Abacus Concepts, Berkeley, CA, USA). Student's $t$ test was used to analyze continuous data, the $\chi^{2}$ or Fisher's exact tests to analyze categorical data. Several variables were selected and compared, including age, gender, smoking habit, co-morbidities (arterial hypertension, diabetes mellitus, chronic obstructive pulmonary disease, hyperlipidemia, obesity), New York Heart Association class, body mass index, blood gas analyzed values $\left(\mathrm{pH}, \mathrm{PaO}_{2}, \mathrm{PaCO}_{2}, \mathrm{SaO}_{2}\right.$, hemoglobin, $\left.\mathrm{HCO}_{3}\right), \mathrm{PEF}, 6 \mathrm{MWT}$, postoperative pulmonary complications and length of inhospital stay. Intraoperative surgical computed variables were the duration of intervention, cardiopulmonary bypass and aortic cross-clamp times, type of procedures. All continuous variables were expressed as mean values plus or minus one standard deviation of the mean. A $p$-value less than 0.05 was considered statistically significant.

\section{Results}

Fifty-nine patients were randomly assigned to group A (respiratory physiotherapy) $(n=19)$, to group B (respiratory and motor physiotherapy) $(n=20)$ and to group C (control group) $(n=20)$. Six patients initially enrolled were not included in the study for reasons not dependent on the treatment in question (i.e., prolonged intensive care unit stay, death). All three groups of patients had similar baseline demographic and preoperative clinical characteristics, except for higher incidence of hypertension in group $C$, and similar surgical variables, i.e. type of surgical procedures, mean duration of surgical procedures, cardiopulmonary bypass and aortic cross-clamp times (Table I). Preoperative blood gas analysis showed similar values of $\mathrm{pH}, \mathrm{PaCO}_{2}, \mathrm{PaO}_{2}, \mathrm{SaO}_{2}$, hemoglobin, and bicarbonate ion concentration in the three groups of patients ( $p>0.3$, for all comparisons).

Preoperatively and postoperatively, at 6MWT both group A and group $B$ patients achieved a significantly higher running autonomy expressed in meters traveled as compared with the untreated group C (Table II). Furthermore, in the postoperative period the temporary decrease in motor activity related, as expected, to the surgical intervention, was lower in the two treated groups in comparison with group $\mathrm{C}$

Table I. Patient population characteristics

\begin{tabular}{|c|c|c|c|c|}
\hline Characteristics & $\begin{array}{l}\text { Group A } \\
(n=19)\end{array}$ & $\begin{array}{l}\text { Group B } \\
(n=20)\end{array}$ & $\begin{array}{l}\text { Group C } \\
(n=20)\end{array}$ & $P$-value \\
\hline Gender (M/F) & $12 / 7$ & $14 / 6$ & $17 / 3$ & NS \\
\hline Age (mean \pm SD) [years] & $62.6 \pm 12.7$ & $63.6 \pm 8.9$ & $64.6 \pm 10.9$ & NS \\
\hline $\mathrm{BMI}($ mean $\pm \mathrm{SD})$ & $26.8 \pm 4.3$ & $26.3 \pm 3.4$ & $27.2 \pm 4.1$ & NS \\
\hline NYHA class (mean \pm SD) & $2 \pm 0.9$ & $2 \pm 0.8$ & $2.4 \pm 0.8$ & NS \\
\hline \multicolumn{5}{|l|}{ Cardiovascular risk factors: } \\
\hline Hypertension & 11 & 7 & 18 & 0.001 \\
\hline Diabetes & 7 & 4 & 5 & NS \\
\hline Dyslipidemia & 4 & 4 & 4 & NS \\
\hline Obesity & 3 & 1 & 3 & NS \\
\hline Smokers & 5 & 4 & 3 & NS \\
\hline Ex-smokers & 4 & 3 & 9 & NS \\
\hline \multicolumn{5}{|l|}{ Surgical procedures: } \\
\hline Bentall, ascending aorta replacement & 1 & 5 & 3 & NS \\
\hline Aortic valve replacement & 9 & 7 & 9 & NS \\
\hline Mitral valve replacement & 4 & 4 & 0 & NS \\
\hline Coronary artery bypass graft & 5 & 4 & 8 & NS \\
\hline Operative time (mean \pm SD) & $286.1 \pm 68.8$ & $293.7 \pm 91.9$ & $296.2 \pm 69.1$ & NS \\
\hline CPB time (mean \pm SD) [min] & $124.1 \pm 55.3$ & $112.8 \pm 44.4$ & $127.8 \pm 54.1$ & NS \\
\hline Cross-clamp time (mean \pm SD) [min] & $100 \pm 48.1$ & $92.350 \pm 38.790$ & $101.1 \pm 47.2$ & NS \\
\hline
\end{tabular}

BMI - body mass index, NYHA - New York Heart Association, CPB - cardiopulmonary bypass, SD - standard deviation, NS - not significant. 
Table II. Six-minute walking test

\begin{tabular}{|c|c|c|c|}
\hline Group & $\begin{array}{l}\text { Preoperative } \\
\text { values }[\mathrm{m}]^{*}\end{array}$ & $\begin{array}{l}\text { Postoperative } \\
\text { values }[\mathrm{m}]^{* *}\end{array}$ & $\begin{array}{c}\text { Difference } \\
\text { (postop. vs. preop.) }\end{array}$ \\
\hline $\mathrm{A}(n=19)$ & $364.47 \pm 108.43$ & $290.79 \pm 109.68$ & -73.7 \\
\hline $\mathrm{B}(n=20)$ & $437.50 \pm 64.63$ & $387.50 \pm 82.52$ & -50.0 \\
\hline$C(n=20)$ & $295.00 \pm 95.49$ & $212.50 \pm 70.49$ & -82.5 \\
\hline
\end{tabular}

(Fig. 1). As shown in Table II and in Figure 1, group B obtained the best results, both in the pre- and postoperative period, also when compared to group A. Table II also reports the difference in meters in the pre- and the postoperative period between the three groups of patients.

Preoperative and postoperative PEF values were significantly better in the two groups of treated patients in comparison with group $\mathrm{C}$. As shown for the 6MWT, also the decrease of PEF value in the postoperative period was significantly lower in the treated groups of patients (Fig. 2, Table III).

At discharge the mean value of $\mathrm{PaO}_{2}$ in ambient air was significantly higher in groups $\mathrm{A}$ and $\mathrm{B}$ in comparison with group C (68.5 \pm 7.3 and $72.6 \pm 9.2 \mathrm{~mm} \mathrm{Hg}$ vs. $63.9 \pm 6.9 \mathrm{~mm} \mathrm{Hg}$, $p=0.047$ and $p=0.002$, respectively). The mean value of $\mathrm{SaO}_{2}$ was significantly higher in group $\mathrm{B}$ in comparison with group C ( $97.4 \pm 1.3 \%$ vs. $95.9 \pm 2.1 \%, p=0.013)$ (Table IV, Figs. 3, 4).

The incidence of pulmonary complications was $5.3 \%$ in group $\mathrm{A}$ (primary respiratory distress requiring re-intubation in 1 patient), absent in group $B, 10 \%$ in group C (pleural effusion requiring drainage in 1 patient, infection requiring antibiotic therapy in another one) $(p=0.11)$. In group $B$ the

Table III. Peak expiratory flow

\begin{tabular}{lccc} 
Group & $\begin{array}{c}\text { Preoperative } \\
\text { values [l/min] }\end{array}$ & $\begin{array}{c}\text { Postoperative } \\
\text { values [l/min]** }\end{array}$ & $\begin{array}{c}\text { Difference } \\
\text { (postop. vs. preop.) }\end{array}$ \\
$\mathrm{A}(n=19)$ & $3.31 \pm 1.58$ & $2.50 \pm 1.40$ & -0.81 \\
\hline $\mathrm{B}(n=20)$ & $3.12 \pm 1.64$ & $2.43 \pm 1.56$ & -0.69 \\
\hline $\mathrm{C}(n=20)$ & $2.24 \pm 1.34$ & $1.38 \pm 0.66$ & -0.86 \\
\hline
\end{tabular}

${ }^{*} P=$ not significant (group B vs. group A); $p=0.070$ (group B vs. group C); $p=0.028$ (group A vs. group C). ${ }^{* *} P=$ not significant (group B vs. group A); $p=0.008$ (group B vs. group C); $p=0.003$ (group A vs. group C).

Table IV. Postoperative blood gas analysis measurements

\begin{tabular}{lccc} 
Measurements & $\begin{array}{c}\text { Group A } \\
(n=19)\end{array}$ & $\begin{array}{c}\text { Group B } \\
(n=20)\end{array}$ & $\begin{array}{c}\text { Group C } \\
(n=20)\end{array}$ \\
$\mathrm{PaO}_{2}[\mathrm{~mm} \mathrm{Hg}]^{*}$ & $72 \pm 9$ & $69 \pm 7$ & $64 \pm 7$ \\
\hline $\mathrm{PaCO}_{2}[\mathrm{~mm} \mathrm{Hg}]$ & $34 \pm 3$ & $34 \pm 3$ & $34 \pm 3$ \\
\hline $\mathrm{SaO}_{2}(\%)^{* *}$ & $97 \pm 1$ & $97 \pm 1$ & $96 \pm 2$ \\
\hline $\mathrm{pH}$ & 7.49 & 7.49 & 7.50 \\
\hline $\mathrm{Hemoglobin}[\mathrm{g} / \mathrm{dl}]$ & $10.8 \pm 1.6$ & $10.9 \pm 1.5$ & $10.3 \pm 0.9$ \\
\hline $\mathrm{HCO}_{3}[\mathrm{mmol} / \mathrm{l}]$ & $26 \pm 3$ & $26 \pm 2$ & $27 \pm 3$ \\
\hline
\end{tabular}

${ }^{*} P=$ not significant (group B vs. group A); $p=0.047$ (group B vs. group C); $p=0.003$ (group A vs. group C). ${ }^{* *} P=$ not significant (group B vs. group A) $p=0.090$ (group B vs. group C); $p=0.013$ (group A vs. group C).

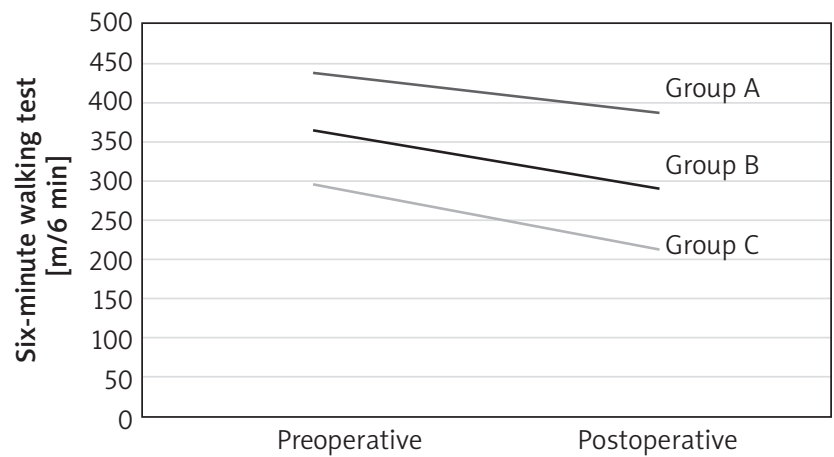

Fig. 1. Six-minute walking test, comparison between group A, B, C, preoperatively and postoperatively

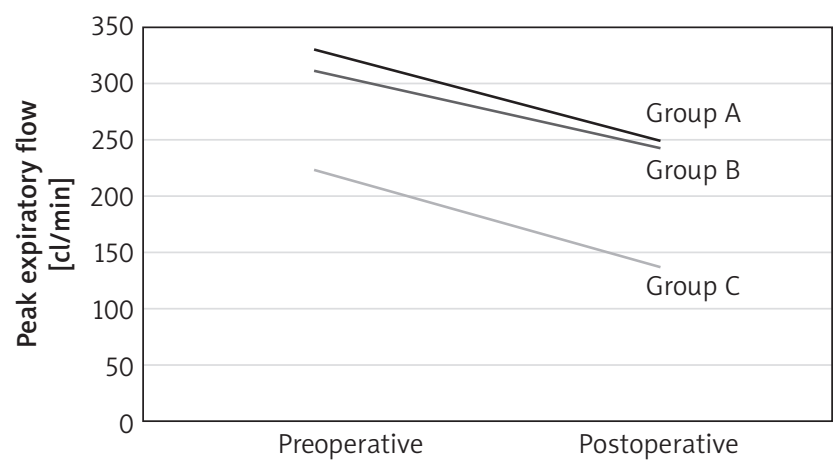

Fig. 2. Peak expiratory flow method, comparison between group $A$ $\mathrm{B}, \mathrm{C}$, preoperatively and postoperatively

postoperative length of in-hospital stay (7.4 \pm 1.2 days) was significantly shorter in comparison with groups A $(9.7 \pm 4.0$ days) and C (12.6 \pm 9.9 days) ( $p=0.02$, for both comparisons).

\section{Discussion}

Patients undergoing cardiac surgery may have postoperative functional impairment significantly compromising their recovery capacity and level of autonomy and generally leading to pulmonary dysfunction and to reduced tolerance to exercise related to sternotomy, to cardiopulmonary

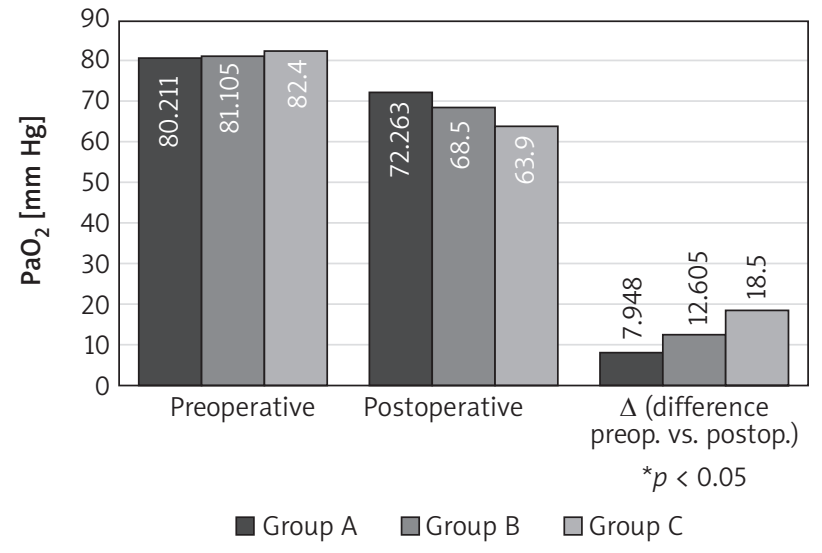

Fig. 3. Oxygen partial arterial pressure $\left(\mathrm{PaO}_{2}\right)$ in blood, comparison between group A, B, C, preoperatively and postoperatively 


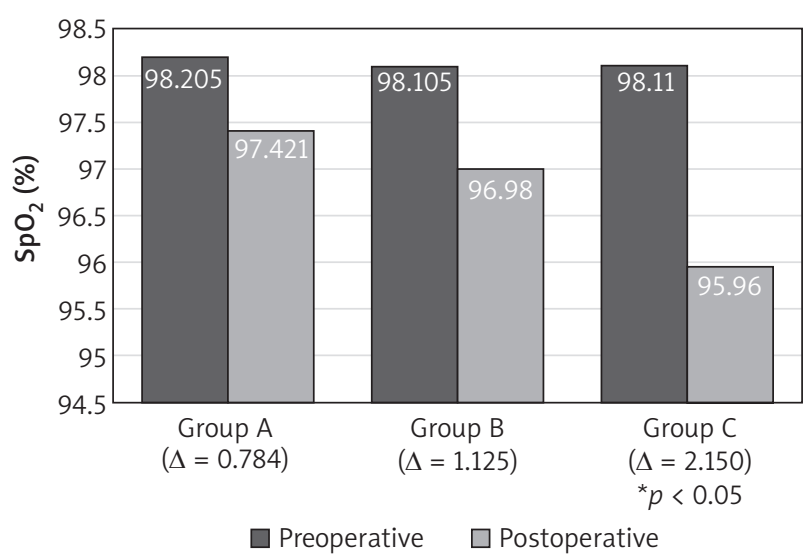

Fig. 4. Oxygen arterial saturation (\%) in blood, comparison between group A, B, C, preoperatively and postoperatively

bypass and reduced physical activity [6, 9, 22]. Training programs based on respiratory and musculoskeletal physiotherapy thus become the cornerstone for a better postoperative recovery. Although the benefits of post-surgical rehabilitation are well documented, less is known about the role that a preoperative rehabilitation protocol may have on the postoperative outcome of patients undergoing cardiac surgery.

The main aim of our study was therefore to investigate how a preoperative training protocol based on the increase of respiratory capacity, muscle strength and exercise tolerance could reduce the expected functional decrease observed in patients undergoing cardiac surgery [23-26]. By comparing the three groups examined, it was possible to highlight better physical and respiratory conditions in patients of the two groups treated preoperatively in comparison with the control group, either before cardiac surgery, or in the postoperative period in terms of the distance walked at the 6MWT and value of the PEF (Tables II, III, Figs. 1, 2). In particular, as compared with group $C$, in group $A$ and $B$ patients the distance traveled in meters was about 30-40\% longer and the PEF value was greater than $50 \%$. Moreover, in the postoperative period the patients subjected to the respiratory and motor physiotherapy protocol showed a minor reduced tolerance to exercise and better PEF values in comparison to those observed in group C (Figs. 1, 2). Similarly, the reduction in $\mathrm{PaO}_{2}$ and $\mathrm{SaO}_{2}$ values observed after surgery in comparison with the preoperative period was not statistically significant in the two groups of treated patients, while in the control group it was reduced with statistical significance (Table IV, Figs. 3, 4). As also reported in other studies $[27,28]$. We observed a low rate of postoperative pulmonary complications in the treated groups of patients in comparison with the control group, although this difference did not reach statistical significance.

Finally, the length of postoperative in-hospital stay observed in group $B$ was reduced in comparison with that of the other two groups, but due to the relatively small sample of the study, it was not possible to identify a statistically significant difference that would enable us to draw relevant conclusions on this clinical aspect.
This study could indicate that the performance of the rehabilitation program before cardiac surgery can be recommended to all patients if possible, in order to make the post-operative period less traumatic, and to facilitate a faster functional recovery.

\section{Limitations of the study}

The main limitation of our study is represented by the small sample of analyzed patients, and data obtained can be considered preliminary results of an initial evaluation.

However, this study showed that both integrated respiratory and motor preoperative physiotherapy can yield better results than those observed in the control group, playing an essential role in accelerating the recovery of respiratory and musculoskeletal function, thus ensuring an earlier recovery.

\section{Conclusions}

As compared to the control group, substantially better clinical results were found in the groups preoperatively treated with physiotherapeutic protocols immediately before as well as after cardiac surgery. In all three groups, as expected, there was a decrease in the postoperative period of the measured values due to the surgical trauma, but group A and B achieved overall better results in the forced expiratory test, in the control of respiratory values at the blood gas analysis, and in their physical activity.

\section{Disclosure}

The authors report no conflict of interest.

\section{References}

1. Leon AS, Franklin BA, Costa F, Balady GJ, Berra KA, Stewart KJ, Thompson PD, Williams MA, Lauer MS; American Heart Association; Council on Clinical Cardiology (Subcommittee on Exercise, Cardiac Rehabilitation, and Prevention); Council on Nutrition, Physical Activity, and Metabolism (Subcommittee on Physical Activity); American association of Cardiovascular and Pulmonary Rehabilitation. Cardiac rehabilitation and secondary prevention of coronary heart disease: an American Heart Association scientific statement from the Council on Clinical Cardiology (Subcommittee on Exercise, Cardiac Rehabilitation, and Prevention) and the Council on Nutrition, Physical Activity, and Metabolism (Subcommittee on Physical Activity), in collaboration with the American association of Cardiovascular and Pulmonary Rehabilitation. Circulation 2005; 111: 369-376.

2. Herdy AH, Marcchi PL, Vila A, Tavares C, Collaço J, Niebauer J, Ribeiro JP. Preand postoperative cardiopulmonary rehabilitation in hospitalized patients undergoing coronary artery bypass surgery: a randomized controlled trial. Am J Phys Med Rehabil 2008; 87: 714-719.

3. da Costa Torres D, Dos Santos PM, Reis HJ, Paisani DM, Chiavegato LD. Effectiveness of an early mobilization program on functional capacity after coronary artery bypass surgery: a randomized controlled trial protocol. SAGE Open Med 2017; 4: 2050312116682256.

4. Rawat N, Yang T, Ali KJ, Catanzaro M, Cohen MD, Farley DO, Lubomski LH, Thompson DA, Winters BD, Cosgrove SE, Klompas M, Speck KA, Berenholtz SM. Two-state collaborative study of a multifaceted intervention to decrease ventilator-associated events. Crit Care Med 2017; 45: 1208-1215.

5. Moreno AM, Castro RRT, Sorares PPS, Sant' Anna M, Cravo SL, Nóbrega AC. Longitudinal evaluation the pulmonary function of the pre and postoperative periods in the coronary artery bypass graft surgery of patients treated with a physiotherapy protocol. J Cardiothorac Surg 2011; 6: 62.

6. Canet J, Gallart L, Gomar C, Paluzie G, Vallès J, Castillo J, Sabaté S, Mazo V, Briones Z, Sanchis J; ARISCAT group. Prediction of postoperative pulmonary 
complications in a population-based surgical cohort. Anesthesiology 2010; 113: 1338-1350.

7. Hulzebos EH, Van Meeteren NL, De Bie RA, Dagnelie PC, Helders PJ. Prediction of postoperative pulmonary complications on the basis of preoperative risk factors in patients who had undergone coronary artery bypass graft surgery. Phys Ther 2003; 83: 8-16.

8. Stammers AN, Kehler DS, Afilalo J, Avery LJ, Bagshaw SM, Grocott HP, Légaré JF, Logsetty S, Metge C, Nguyen T, Rockwood K, Sareen J, Sawatzky JA, Tangri N, Giacomantonio N, Hassan A, Duhamel TA, Arora RC. Protocol for the PREHAB study-pre-operative rehabilitation for reduction of hospitalization after coronary bypass and valvular surgery: a randomised controlled trial. BMJ Open 2015; 5: e007250.

9. Arthur HM, Daniels C, McKelvie R, Hirsh J, Rush B. Effect of a preoperative intervention on preoperative and postoperative outcomes in low-risk patients awaiting elective coronary artery bypass graft surgery. A randomized, controlled trial. Ann Intern Med 2000; 133: 253-262.

10. Cavenaghi S, Ferreira LL, Marino LHC, Lamari NM. Respiratory physiotherapy in the pre and postoperative myocardial revascularization surgery. Rev Bras Circ Cardiovasc 2011; 26: 455-461.

11. Çırak Y, Karahan Z, Yelvar GDY, Erden I, Demirkılıç U, Erden I, Demirkılıç U. Is physiotherapy effective on the occurrence of postoperative pulmonary complications in patients undergoing coronary artery bypass graft surgery? A randomised controlled trial. Türk Göğüs Kalp Damar 2015; 23: 622-630

12. Valkenet K, Trappenburg JCA, Hulzebos EH, van Meeteren NLU, Backx FJG. Ef fects of a pre-operative home-based inspiratory muscle training programme on perceived health-related quality of life in patients undergoing coronary artery bypass graft surgery. Physiotherapy 2017; 103: 276-282

13. Achttien RJ, Staal JB, van der Voort S, Kemps HM, Koers H, Jongert MW, Hendriks EJ; Practice Recommendations Development group. Exercise-based cardiac rehabilitation in patients with coronary heart disease: a practice guideline. Neth Heart J 2013; 21: 429-438.

14. Leguisamo CP, Kalil RAK, Furlani AP. Effectiveness of a preoperative physiotherapeutic approach in myocardial revascularization. Braz J Cardiovasc Surg 2005; 20: 134-141.

15. Brooks D, Solway S, Gibbons WJ. ATS statement: guidelines for the six-minute walk test. Am J Respir Crit Care Med 2003; 167: 1287.
16. Wilson RC, Jones PW. Long-term reproducibility of Borg scale estimates of breathlessness during exercise. Clin Sci 1991; 76: 277-282.

17. Tsukioka K. [Peak expiratory flow (PEF)]. Nihon Rinsho 2001; 59: 1955-1959.

18. Lellouche F, Delorme M, Bussières J, Ouattara A. Perioperative ventilatory strategies in cardiac surgery. Best Pract Res Clin Anaesthesiol 2015; 29: 381-395.

19. Kiel M. Cardiac rehabilitation after heart valve surgery. PM R 2011; 3: 962-967.

20. Waite I, Deshpande R, Baghai M, Massey T, Wendler O, Greenwood S. Homebased preoperative rehabilitation (prehab) to improve physical function and reduce hospital length of stay for frail patients undergoing coronary artery bypass graft and valve surgery. J Cardiothor Surg 2017; 12: 91.

21. Tonelli R, Cocconcelli E, Lanini B, Romagnoli I, Florini F, Castaniere I, Andrisani D, Cerri S, Luppi F, Fantini R, Marchioni A, Beghè B, Gigliotti F, Clini EM. Effectiveness of pulmonary rehabilitation in patients with interstitial lung disease of different etiology: a multicenter prospective study. BMC Pulm Med 2017; 17: 130

22. Shakouri SK, Salekzamani Y, Taghizadieh A, Sabbagh-Jadid H, Soleymani J, Sahebi L, Sahebi R. Effect of respiratory rehabilitation before open cardiac surgery on respiratory function: a randomized clinical trial. J Cardiovasc Thorac Res 2015; 7: 13-17.

23. Hulzebos EH, Smit Y, Helders PP, van Meeteren NL. Preoperative physical therapy for elective cardiac surgery patients. Cochrane Database Syst Rev 2012; 11: CD010118.

24. Cordeiro A, Melo T, Neves D, Luna J, Esquivel MS, Guimaraes ARF, Borges DL, Petto J. Inspiratory muscle training and functional capacity in patients undergoing cardiac surgery. Braz J Cardiovasc Surg 2016; 31: 140-144.

25. Moradian ST, Najafloo M, Mahmoudi H, Ghiasi MS. Early mobilization reduces the atelectasis and pleural effusion in patients undergoing coronary artery bypass graft surgery: a randomized clinical trial. J Vasc Nurs 2017; 35: 141145.

26. Snowdon D, Haines TP, Skinner EH. Preoperative intervention reduces postoperative pulmonary complications but not length of stay in cardiac surgical patients: a systematic review. J Physiother 2014; 60: 66-77.

27. Valkenet K, de Heer F, Backx FJ, Trappenburg JC, Hulzebos EH, Kwant S, van Herwerden LA, van de Port IG. Effect of inspiratory muscle training before cardiac surgery in routine care. Phys Ther 2013; 93: 611-619. 